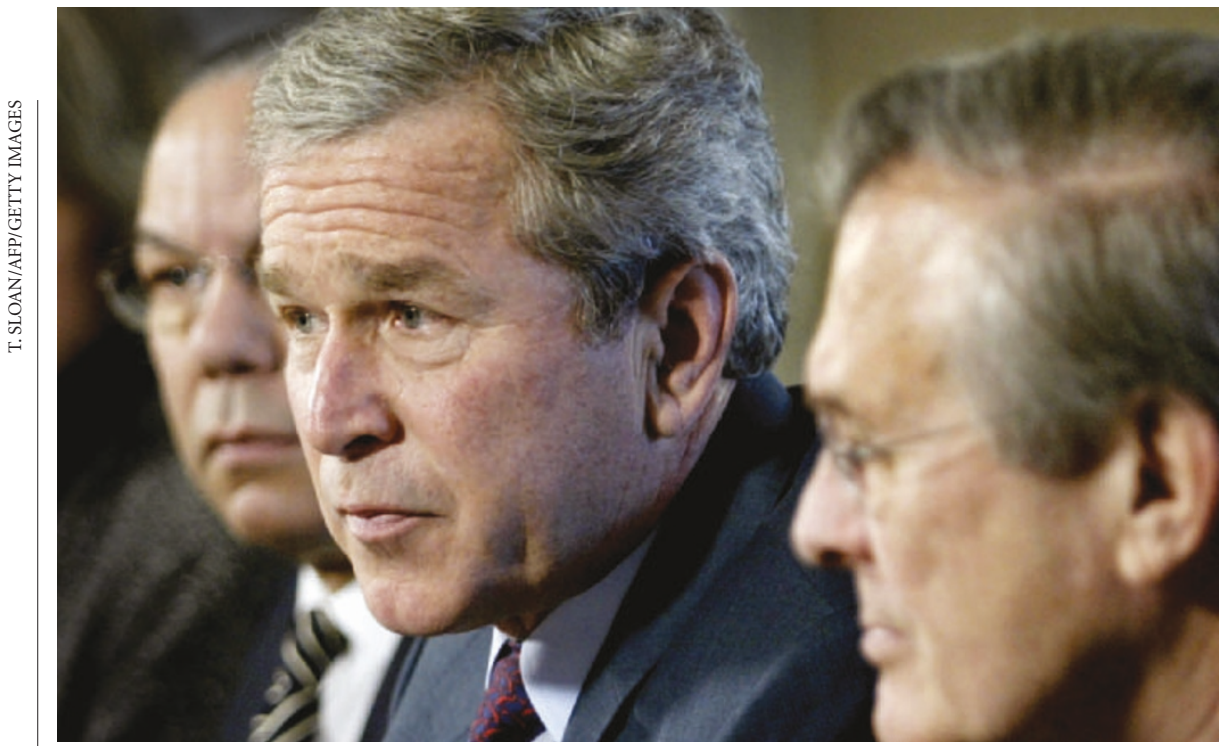

Balancing the books: President Bush shares his budget proposal with members of his Cabinet.

\section{Bush's belt-tightening budget offers science slim pickings}

\section{Geoff Brumfiel, Washington}

A decade of strong growth in US research funding came to an abrupt halt on 2 February, when President Bush released a budget proposal that attempts to confront the nation's massive financial deficit.

The budget for the 2005 fiscal year, which begins on 1 October, offers little new money for researchers. Funding for the National Institutes of Health (NIH) and the National Science Foundation (NSF) would struggle to keep up with inflation, and programmes at most other major agencies are cut. Supporters of science in Congress have vowed to push for more funding as the budget takes final shape there this summer - but few lobbyists hold out much hope that they will succeed.

Administration officials put a positive spin on the numbers. John Marburger, the president's science adviser, told a briefing at the National Academies in Washington DC that the budget allocates a record $\$ 132$ billion to research and development in 2005 $5 \%$ more than last year.

But science advocates point out that almost all of that extra money goes to evaluating military equipment. The budget for 'federal science and technology' - the definition set by the National Academies as the measure for innovative research and development would be $\$ 60.4$ billion, $0.5 \%$ less than 2004 (see chart). "This is a slight, across-the-board cut for science," says Mike Lubell, director of public affairs at the American Physical Society.

At the NIH, which funds most biomedical research in the United States, funding would increase by $2.6 \%$ to $\$ 28.6$ billion. Much of the new money is directed at biodefence research, which would grow by $7.5 \%$ to $\$ 1.7$ billion. $\mathrm{NIH}$ director Elias Zerhouni called the current budget climate "difficult" because
US federal science and technology budget

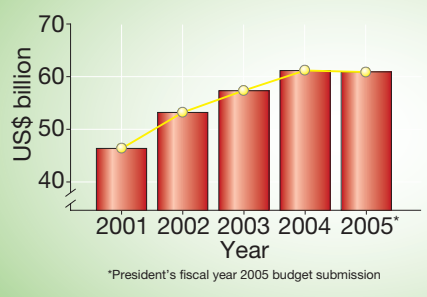

the agency must contend with bioterrorism, while continuing to fund multi-year research grants. The NIH plans to fund only about 250 new research grants in 2005. "They are spreading resources more thinly," says Pat White, head of federal relations at the Association of American Universities.

The NSF, which distributes most nonbiomedical research grants at US universities, would see a $3 \%$ increase to $\$ 5.75$ billion. This is above what some other agencies are being offered, but is far below the level suggested by a law passed in 2002, which recommended doubling the NSF's budget over five years. "The NSF has faired pretty well, relatively speaking," director Rita Colwell says. But in a show of frankness unusual for an agency chief, Colwell adds that "it would be disingenuous to say that this is all that we had hoped for."

The Department of Energy's office of science, which funds most US physics, sees its budget cut by $2 \%$ to $\$ 3.4$ billion.

With both Congress and the administration trying to tame the half-a-trillion-dollar deficit ahead of November's elections, science advocates will have their work cut out getting more money before the budget is finalized. In the words of one senate staffer: "This is going to be ugly."

Additional reporting by Paul Smaglik, Tony Reichhardt and Erika Check.

\section{Boost for biodefence}

The National Institutes of Health's budget includes $\$ 150$ million to build 20 'biosafety level 3' secure labs for investigating hazardous biological materials. Once completed, they will conduct about 200 projects finding ways to protect the public from bioterrorism.

At the Centers for Disease Control and Prevention in Atlanta, Georgia, the overall 2005 budget is down by $1 \%$. But a new, $\$ 130$ million biosurveillance programme is proposed to monitor the 'quiet' spread of diseases by tracking non-patient data, such as sales of particular pharmaceuticals.

\section{Military might}

The Pentagon's overall budget is boosted by $7 \%$ to $\$ 400$ billion, but researchers and grant recipients won't see any of the extra cash.

Basic and applied research at the defence department - the main source of support for computer science and engineering research in US universities - would be cut by $11 \%$ to $\$ 5.2$ billion.

But funding for the deployment of missile defence systems - whose efficacy has been questioned by US physicists (see Nature $\mathbf{4 2 4}$, 240 ; 2003) - will rise by $13 \%$ to $\$ 10.3$ billion.

\section{Moonbound, eventually...}

Since President Bush announced his goal to return astronauts to the Moon (see Nature 427, 273; 2004), the question has been how NASA will pay for it. A little light was shed on this in the agency's budget proposal, which sees its overall allocation rise by $5.6 \%$ to $\$ 16.2$ billion.

Most of the money for the new programme will come from converting existing rocket development work to designing new vehicles and phasing out the space shuttle. Scientists will have to make sacrifices too. A proposed 'Beyond Einstein' initiative to study dark matter and black holes would be deferred. Spending on Earth science would drop by $8 \%$ and space science would grow at a slower rate than projected last year. But Mars-related science and technology is up by $16 \%$ to $\$ 691$ million.

\section{but less joy on Earth}

Environmental science programmes are among those hardest hit in the entire proposal. The budget for science and technology at the Environmental Protection Agency (EPA) is cut by $12 \%$ to $\$ 577$ million. Research at the National Oceanic and Atmospheric Administration is down $3 \%$ to $\$ 350$ million, and research at the US Geological Survey is down by $2 \%$ to $\$ 920$ million.

Mark Udall (Democrat, Colorado), senior minority party member on the House subcommittee overseeing environmental research, says: "I am very disappointed. This is a budget lacking vision." 